\section{d ditror.}

\author{
OF
}

\section{HOSPITAL PRACTICE, BRITISH AND FOREIGN.}

Nulla autem est alia pro certo noscendi via, nisi quamplurimas et morborum et dissectionum historias, tum aliorum tum proprias collectas habere, et inter se comparare.-MoRgAGNI De Sed. et Caus. Morb, lib. iv. Procmium.

\section{LONDON TEMPERANCE HOSPITAL.}

A CASE OF PIROGOFH'S AMPUTATION.

(Under the care of Dr. W. J. Collins.)

WHEN amputation at the ankle is required for disease of the foot there is a general consensus of opinion that Syme's operation affords a better chance of the complete removal of the disease than Pirogoff's, in which a portion of the os calcis is retained. This is especially the case in tuberculosis of the tarsus, for it is rare to find such extensive disease of the tarsal bones as to require amputation without the calcaneum being affected. In the case of amputation for injury obviously this objection does not apply. Instrument makers assert that it is more difficult to adapt an artificial foot to a Pirogoff stump than to that resulting from a Syme's amputation, but this is really an imaginary difficulty. The greater suitability of the stump for walking is the chief reason for preferring the Pirogoff operation to the other; in the former it is practically the thick heel pad supported by a rounded bony surface which comes in contact with the ground, while in Syme's the freshly sawn surfaces of the tibia and fibula press against the skin flap.

A boy, aged thirteen years, whose family history was unimportant, was said to have injured his right foot when jumping some three weeks before his admission to the London Temperance Hospital on Nov. 3rd, 1896; an abscess formed and broke below the internal malleolus, leaving a

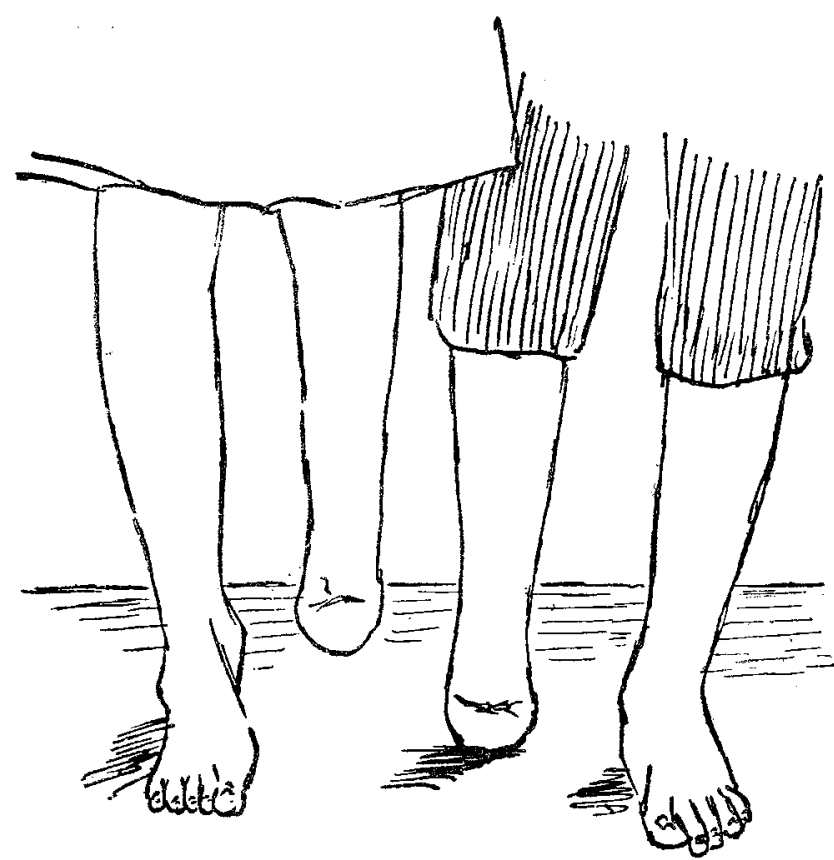

Sketch showing relative lengths of stumps after Syme's and Pirogoff's amputations.

sinus which was discharging. A probe indicated carious bone. The patient was in much pain and was subject to starting at night; the temperature in the evening ran up to about $101^{\circ} \mathrm{F}$. A week later no improvement had resulted from rest; the boy looked worse, was losing weight, and was in much pain. On the 11th, under chloroform, Dr. Collins performed Pirogoff's amputation of the foot. The sawn surfaces of the tibia and os calcis appeared to be healthy to the naked eye, and were brought into accurate apposition by silk sutures passed through foramina bored with a brad-awl. The wound healed well, though the temperature ranged high for a week or two. On Jan. 2nd, 1897, he conld walk without a boot and was gaining weight rapidly. When fitted with a dummy foot he walked withont any lurch, and so well that some who saw him could not believe that the foot had been amputated.

Remarks by Dr. CoLlins.-The Moscow meeting will doubtless afford occasion for reviving the fame won by Nikolaus Pirogoff in many fields of human activity. As a profound anatomist, a military surgeon, a hospital organiser, and a university reformer he has impressed his rugged personality upon the history of his time. True, that to the ordinary English student his name is known almost exclusively by his osteoplastic modification of Syme's amputation. of which an account with a diagram is to be found in his "Klinische Chirurgie," published at Leipzig in 1854 . But this improvement in amputation of the foot, as he practised it, as also as more recently modified by Lefort and Günther, was in itself a valuable reform. I recently happened to have in my wards two children of about the same age and height; in one case I performed Syme's amputation as the caries was too extensive to save any of the tarsus, and in the other case (the notes of which are given above) I performed Pirogoff's modified operation. It occurred to me to photograph the patients side by side. The accompanying illustration (which I have reproduced faithfully from the photograph) shows the advantage in length in the case of the boy as against the shortening in that of the girl, in which Syme's unmodified operation was done. The difference in the gait was not less noticeable even when the shortening in the latter case was corrected by a cork sole.

\section{ROYAL INFIRMARY, NEWCASTLE-UPON- TYNE.}

A CASE OF RELAPSING PNEUMONIA.

(Under the care of Dr. THOMAs OLIVER.)

A MAN, aged twenty-three years, was, on Nov. 26th, 1896, admitted into the Newcastle Royal Infirmary under the care of Dr. Oliver. As the patient was delirious no history of the illness was at this stage obtainable, except from the remark volunteered by a friend that he had been in bed for five days. Subsequently when he recovered it was ascertained from him that while at work on the 21st he had been suddenly seized with a violent shivering at $11 \mathrm{~A} . \mathrm{M}$, , that do what he might he could not get himself warm, and that in the afternoon he felt so unwell he was obliged to go to bed. On the morning after his admission into the infirmary he had a flushed face and rapid breathing, his mind was still wandering, and he was the subject of short cough and rusty expectoration. He was too ill for a careful examination to be made. All that could be done, therefore, was to make an examination of the front of the chest, by which was detected a limited area that was dull on percussion, commencing a few inches below the right clavicle, and over this area distinct tubular breathing could be heard. The left chest and heart were healthy. On the $28 \mathrm{th}$, while there was evidence of the percussion note over the upper part of the right chest being less dull, there was detected a small area of dulness external to the right nipple and also that the base of the lung was dull. The area which gave this altered percussion note extended in an upward but slanting direction towards the axilla. On examining the chest posteriorly tubular breathing could be heard from the inferior angle of the right scapula downwards. Although the breathing was rapid (56 to the minute) there was no actual dyspnoea, the pulse was 110 , and the temperature was $102^{\circ} \mathrm{F}$., having fallen $2^{\circ}$ since the previous night. Later in the course of the day there was a considerable degree of muscular twitching, but this disappeared on discontinuing the liquor strychninæ which for the past two days he had been taking. On the 30th he seemed to be rather better. His temperature on the previous afternoon was $105.2^{\circ}$, but by midnight it had fallen to $98.4^{\circ}$, and with the fall of his temperature the delirium disappeared. For brevity's sake, although the four hours' chart is quoted from, it is not reproduced. For the next two days the patient seemed on the whole to be fairly well; but although his temperature had fallen he rever exhibited that look of well-being which is discernible in any one who, having passed successfully through a sharp illness like pneumonia, may be said to have "turned the corner." He was heary and listless, so much so that when, after remaining thus for a few days, and the temperature again began to rise, and the dulness at the right 
base had extended to the sixth rib, the possibility of temperature began to fall on the sixth and seventh days, a commencing empyema suggested itself. On Dec. 5th the On the eighth it was subnormal $\left(97 \cdot 4^{\circ}\right.$ ), the pulse was 65 , patient was the subject of a short hacking cough. and the respiration was 24 . He looked pale and was The respiration was 32 and the pulse was 100 ; the tongue prostrate. He had the look of a man who had passed was coated. There was slight diarrhœea, the stools being through a severe illness, but with it all he had a thin and watery, yellow, and of a disagreeable odour. clearer and brighter expression than he had ever bad Although his temperature on the previous night was $1045^{\circ}$ since his admission. On the occasion of his first crisis he was stronger than he was and abler to bear examina- the observer was struck by the want of mental clearness, but tion. The dulness previously detected at the level of in this there were a brightness and intelligence which were the third right rib had entirely disappeared and the not present previously. There was still cough, and the sputa percussion note was now almost hyper-resonant. There were now muco-purulent. It is interesting to note that in was still dulness at the extreme base of the right lung. the second attack of pneumonia the sputa, which had lost Over the upper part of the right lung the breath sounds their typical character, again became rusty on the second were coarse and accompanied by muc ว-crepitant râles, while day of the illness and continued thus until the sixth. 0n at the base a friction sound was heard and there was examining the blood after the first crisis there was almost a rather a deficiency of the respiratory murmur. Beyond a complete absence of leucocytes, bat in this, although a

Name. H _...M .

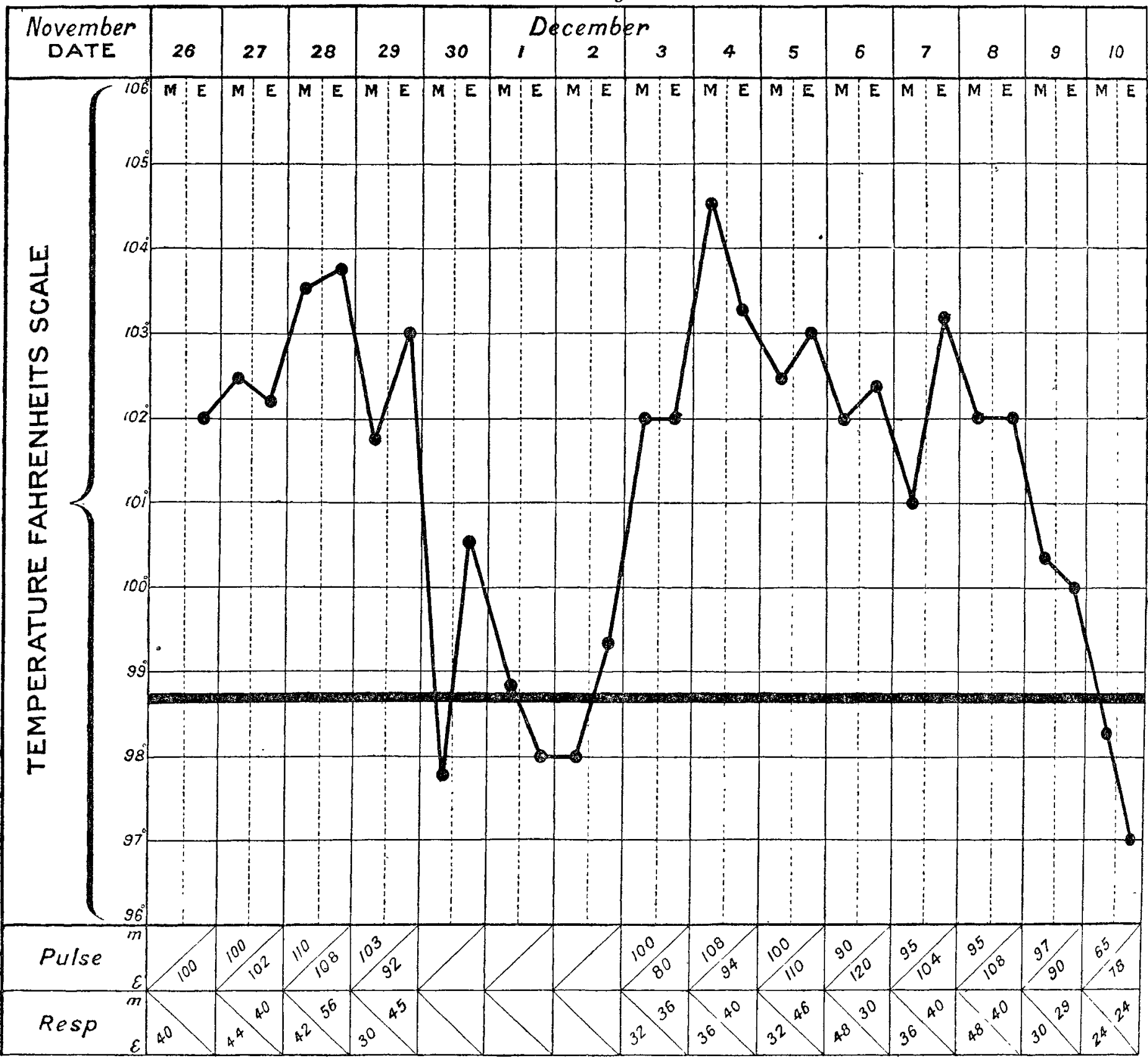

degree of coarseness and loudness of the breath sounds the left lung presented nothing abnormal. The heart was healthy and there was no splenic enlargement. On examining the chest posteriorly the dulness at the right base was most marked in the axillary line, and here the respiratory murmur was deficient. As the physical signs suggested pleural effusion a needle was inserted into the right chest, but only a few drops of dark venous blood were withdrawn. On the 8th there was very marked tubular breathing with increased vocal fremitus and vocal resonance over the extreme right apex, back and front, but especially posteriorly. On the 10th the patient was bathed in perspiration; his breathing was less rapid and his condition, generally speaking, was favourable. On the 11th he still perspired very freely. He had apparently passed through a sezond attack of pneumonia, in which the few more were observed, there was still a very noticeable deficiency. The patient's prostration was still too great to allow of any lengthened physical examination, but there could be detected dulness over the right apex crepitation and bronchial râles, with tubular breathing. On the 14th, although looking pale, the patient was progressing satisfactorily. There was still profuse perspiration; the pulse was 60 , and the respiration was 24 ; the temperature for the past four days had been sub-normal. The expectoration was becoming increasingly less purulent and more mucous, and was gradually diminishing in quantity. Over the right apex there were heard coarse bronchial breathing and large crepitant râles. The heart and the left lung were healthy. The urine thronghout the illness had been free from albumin and sugar. On the 19th the patient looked and felt remarkably well; he tad an excellent 
appetite, and there was no cough or expectoration. The right chest was resonant from the clavicle to almost the base of the lung; the respiratory murmur was full and free, and there was no longer any râle beard in front except at the extreme base, where occasionally a friction sound could be detected during inspiration. In the axillary line there were diminishing dulness at the base, friction sound, and feeble respiratory murmur. These by degrees gradually disappeared, and the patient made an excellent recovery and has maintained (August, 1897) his health since.

Remarks by Dr. Ourven. - Whatever view we hold as to the nature of a recurrence of acute pneumonia in a patient a few days after his apparent recovery, the fact is sufficiently uncommon to attract attention and to merit the few remarks I feel disposed to make upon it. Typical as pneumonia frequently is, it still exhibits many peculiarities, particularly as regards its duration and crisis. A relapse occurs occasionally and may even be repeated. Under most cir. cumstances it is not always easy to distinguish a relapse from a pseudo-crisis, from pneumonia progrediens, or from a form spoken of as migratory and defined by Homburger as a pneumonia which in its course shows successive invasion of different parts of the lung, while the physical signs disappear from the parts first affected. To constitute a true relapse there must have been complete apyrexia and more or less advancing resolution. Osler alludes to pneumonias in which after the subsidence of fever any time between the ninth and eleventh days, and when the temperature has remained normal for a day or two, it again rises and persists for eight or ten days. The second attack is said to be mild, the duration of the pyrexia in the relapse being usually shorter than in the primary illness by several days. Since a true relapse is a rare occurrence we have some difficulty in really knowing what it means. Walshe, in dealing with the question of the frequency of relapse in pneumonia, states on the authority of Briquet that it occurs in one-fiftb, and according to Grisolle in one twenty-eighth of the cases. Our experience certainly leads us to say that Briquet very much overstates the frequency, and, without expressing the ratio in numerical terms, we would simply state that a true relapse announced by a fresh rigor, rusty expectoration, crepitation, and a well-defined period of pyrexia is in this country a very much rarer circumstance than these French physicians would lead us to believe. The patient whose illness supplies the above facts was a young, strongly built, and apparently healtby man, but of such an age as to bave sometimes raised in my mind during the course of his illness the question as to the possible existence of a deeper constitutional malady than pneumonia. It is noteworthy that the relapse was not ushered in by a rigor, but by a fairly rapid rise of temperature and an increased number of respirations; that the sputa became rusty on the second day; that the pyrexia lasted about seren days, terminating in a lysis accompanied by profuse perspiration; and that, just as in a primary attack of pneumonia the physical signs in the chest lagged behind those indicating constitutional disturbance. Some time ago Dr. A. E Wright, ${ }^{1}$ in a paper on the Bacteriology and Pathological Chemistry of Pneumonia read before the Pathological Society of London, showed how, as the crisis in this illness was reached, there occurred the triple phenomenon of disappearance of leucocytes and bacteria from the blood accompanied by tumefaction of the spleen. In my patient the disappearance of leucocytes from the blood after the pseudo-crisis was very noticeable, also after the relapse; but there never occurred any perceptible enlargement of the spleen.

I The Lancet, Feb. 9th, 1895.

North Devon Infirmary, Barnstaple.-The annual meeting of the North Devon Infirmary was held in the board-room on Aug. 27th, Lord Ebrington being in the ohair. The report showed that on June 30 ih, 1896 , there were 44 in-patients remaining under treatment; 691 were admitted during the twelve months, 23 died, and 657 were discharged, leaving 55 under treatment on June 30th, 1897. The out-patients were 2967 in number. The average daily number of inpatients was 51 , the average period of residence being between 25 and 26 days. T'he total income was £3318, including £1211 balance at the banks last year; the expenditure, however, had materially exceeded the income, so that it was necessary to withdraw $£ 500$ from deposit.

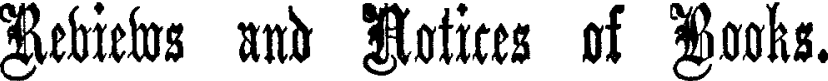

Allgemeine Dermatologie, oder Allgemeine Pathologie, Diagnose und Therapie der Hautkrankheiten. (General Dermatology, or ceneral Pathology, Diagnosis, and Therapeutics of Diseases of the Skin.) Von Dr. ERNST Kromayer. Berlin : Bornträger Brothers, 1896. Price 10 marks.

THIs book, published in the form of lectures, will afford to those acquain' ed with the German tongue a very useful introduction to diseases of the skin. As its name implies, it treats the subject from the general point of view only. Descriptions of spexial discases form no part of its scheme, and diagnosis and therapeatics are dealt with from a broad and general standpoint also. The first part of the book treats of general pathology in its relation to the skin, and the writer justly points out that, owing to its superficial position and accessibility to observation, the skin offers a peculiarly favourable field for the study of pathological processes. The first two lectures are devoted to a detailed account of the structure of the skin and its appendages, illustrated by useful diagrams and micro-photographs. The author then passes on to the subjects of active and passive byperæmia and anæmia of the skin; the account of atonic hyperæmia is a very excellent and lucid one. Subcutaneous and papillary cedema are next dealt with very thoroughly. Inflammation receives attention in three lectures, in which the subject is treated at considerable length and in a scientific spirit. In the next two lectures the author deals with the pathology of the chronic papular and tubercular eruptions, grouping them together on the ground of their common basis in tissue proliferation; the widely different nature of such diseases as tuberculosis, psoriasis, and ringworm leads us to doubt the expediency of such a classification, however excellent the description of the pathological processes in question may be. Hypertrophy. atrophy, pigmentation, new growths, and ulceration form the subjects of the remaining lectures of this the largest section of the book. The section on general diagnosis comprises two lectures only, in which the writer discusses the principles upon which the genus, rather than the species, of the disease is to be determined. The third section consists of three lectures, in which are set forth the principles of dermatological therapeutics and the mode of action of the different groups of remedies. Both these sections are well worthy of attentive study.

We know of no book in the English language, and, indeed, no book of such moderate size in any language, which has precisely the scope and aim of the one before us. We are, indeed, sadly lacking in short but thorough introductory treatises of the kind. No one after reading Dr. Kromayer's lectures can fail to bring to the diagnosis and treatment of skin diseases a clearer mind and a more rational and scientific spirit. We can recommend it heartily to all who can read it in the original, and we trust that it may be worth someone's while to translate it for the benefit of those who are unfamiliar with German.

Manual of Static Electricity in $x$ Ray and Therapeutic Uses. By S. H. MonelL, M.D. New York: W. B. Harison. 1897. Royal 8vo. Pp. 614.

THIs book has a threefold interest, first, because it is the most important book in the English language on Modern Applications of "Statical" Electricity to Therapeutics; secondly, because it supplies reprints, most useful for purposes of reference, of the reports of Addison, GoldingBird, and Sir William Gull on the subject of statical treatment in the earlier part of this century; and, thirdly, 